\title{
The Ancient Tree Inventory: a summary of the results of a 15 year citizen science project recording ancient, veteran and notable trees across the UK
}

\author{
Victoria Nolan $^{1}$ (D) Tom Reader $^{1}$ (D) $\cdot$ Francis Gilbert $^{1}$ (D) $\cdot$ Nick Atkinson ${ }^{2,3,4}$
}

Received: 12 February 2020 / Revised: 5 August 2020 / Accepted: 6 August 2020 /

Published online: 18 August 2020

(C) The Author(s) 2020

\begin{abstract}
Ancient, veteran and notable trees are ecologically important keystone organisms and have tangible connections to folklore, history and sociocultural practices. Although found worldwide, few countries have such a rich history of recording and treasuring these trees as the UK, with its extensive Royal and aristocratic land ownership, unique land management methods and long-standing interest in natural history and species record collecting. As a result, the UK has collated an extensive database of ancient, veteran and notable trees called the Ancient Tree Inventory (ATI). The ATI is the result of a successful, long-term citizen science recording project and is the most comprehensive database of ancient and other noteworthy trees to date. We present here the first review of the ATI in its entirety since its initiation in 2004, including summaries of the UK ancient, veteran and notable tree distributions, the status and condition of the trees, and key information about the recording process and maintenance of the database. Statistical analysis of components of the dataset, comprising 169,967 tree records, suggest there are significant differences in the threats, size, form and location of different types of trees, especially in relation to taxonomic identity and tree age. Our goal is to highlight the value of the ATI in the UK, to encourage the development of similar ancient tree recording projects in other countries, and to emphasise the importance to conservation of continued efforts to maintain and expand databases of this kind.
\end{abstract}

Keywords Conservation · Dead wood $\cdot$ Ecosystem $\cdot$ Keystone species $\cdot$ Saproxylic $\cdot$ Species database

Communicated by David Hawksworth.

This article belongs to the Topical Collection: Forest and plantation biodiversity.

Electronic supplementary material The online version of this article (https://doi.org/10.1007/s10531-02002033-2) contains supplementary material, which is available to authorized users.

Extended author information available on the last page of the article 


\author{
Abbreviations \\ ATF Ancient Tree Forum \\ ATI Ancient Tree Inventory \\ DBH Diameter at breast height \\ NPPF National Planning Policy Framework \\ TPO Tree Preservation Order \\ WT Woodland Trust
}

\section{Background information about ancient, veteran and notable trees}

It is not so much for its beauty that the forest makes a claim upon men's hearts, as for that subtle something, that quality of air that emanation from old trees, that so wonderfully changes and renews a weary spirit

Robert Louis Stevenson (1875-6)

\section{What are ancient trees?}

Trees are thought to grow and age in three phases (White 1998; Read 2000; ATF 2008a, b). These include formative growth from seedling establishment until maturity, the mature phase when the crown reaches maximum size and finally the ancient (or senescent) phase. During this last phase the characteristics associated with ancient or veteran trees emerge, including a hollowing trunk, holes and cavities, deadwood in the canopy, bark loss and the presence of fungi, invertebrates and other saproxylic organisms (Read 2000; Rust and Roloff 2002; ATF 2008a, b; Owen and Alderman 2008). Each phase length differs depending on environmental conditions, management techniques and tree species (Woodland Trust 2001; Fay 2002; ATF 2008a, b; Owen and Alderman 2008).

In the literature, the terms 'veteran', 'notable', 'champion', 'large old' and 'heritage' are often used interchangeably with 'ancient' (Read 2000; Fay 2002; Pautasso and Chiarucci 2008; Lindenmayer et al. 2012), which has led to confusion about why a tree is of particular interest (ATF 2008a, b). In the UK, the Woodland Trust (WT), one of the largest woodland and ancient tree conservation charities, recognised the need to separate and define these terms to provide clarity when classifying trees in relation to age, size or other characteristics (Woodland Trust 2001; ATF 2008a, b; Lonsdale 2013) (Table 1). Subsequent uses of these terms in this paper will follow the WT definitions. As there is overlap between the terms 'ancient' and 'veteran' (i.e. all ancient trees are also veteran trees), any use of the term 'veteran' in this review refers to only trees that are 'non-ancient veterans'.

\section{Value and importance of ancient and other noteworthy trees}

Like all trees, trees showing 'veteran characteristics' contribute to ecosystem services such as carbon storage, water retention and microclimate regulation (Rubino and McCarthy 2003; Lachat et al. 2013; Sist et al. 2014). In addition, they are also a very important source of decaying and dead wood, a rare and declining habitat throughout Europe (Siitonen 2001; Butler et al. 2002), and support a wide range of saproxylic organisms including fungi 
Table 1 Definitions and distinctions between different terms used when discussing ancient and other noteworthy trees according to the Woodland Trust position statement (2001) and the 'Ancient tree guide 4: What are ancient, veteran and other trees of special interest?' (Woodland Trust 2008)

\begin{tabular}{|c|c|}
\hline Term & Description \\
\hline Ancient & $\begin{array}{l}\text { Any tree showing 'veteran' characteristics e.g. hollow trunk, crown retrenchment, crevices and } \\
\text { the presence of saproxylic organisms, and is older than most individuals of the same species. } \\
\text { Age is estimated based primarily on girth (as in White 1998), but also considering the } \\
\text { environment and growing conditions of the tree. Approximate age-girth relationships are } \\
\text { provided for the most common UK tree species (Woodland Trust 2008). All ancient trees are } \\
\text { also veteran and heritage trees, and may or may not be champion trees }\end{array}$ \\
\hline Veteran & $\begin{array}{l}\text { Any tree showing 'veteran' characteristics. All ancient trees are veteran trees, but there are } \\
\text { some younger trees also classed as veterans that show 'veteran' characteristics due to damage } \\
\text { or disease. Veteran trees might also be classed as champion or heritage trees. Throughout this } \\
\text { review, all references to a 'veteran tree' are in relation to only trees that are 'non-ancient } \\
\text { veterans' }\end{array}$ \\
\hline Notable & $\begin{array}{l}\text { The largest or tallest tree per species in a defined local area e.g. a park or garden. A notable tree } \\
\text { has no obvious 'veteran' characteristics }\end{array}$ \\
\hline Champion & $\begin{array}{l}\text { The tallest tree or the tree with the largest girth per species in the UK (or other region e.g. } \\
\text { England). These trees are also all notable trees, and some may or may not be ancient, veteran } \\
\text { or heritage trees }\end{array}$ \\
\hline Heritage & $\begin{array}{l}\text { Trees with connections to historical or cultural events or trees that provide high aesthetic value. } \\
\text { These trees may or may not also be ancient, veteran, notable or champion trees }\end{array}$ \\
\hline
\end{tabular}

(Cooke 1984; Boddy 2001), epiphytes (Read 2000; Butler et al. 2002; Ranius et al. 2008) and invertebrates, especially beetles (Speight 1989; Seibold et al. 2018). It is estimated that $6 \%$ of British invertebrate species rely solely on decaying wood ecosystems (Alexander 1999). In addition, mammals, reptiles and amphibians all make use of ancient and ageing tree habitats (Rasey 2004; Schmeller et al. 2009; Humphrey 2005).

Many ancient and other noteworthy trees have famous cultural and historical ties, which present valuable recreational and tourism opportunities (Rackham 1994; Lonsdale 2013). One of the oldest UK trees, often reported to be around 2000-2500 years old, is the Ankerwycke Yew (Taxus baccata) in Berkshire, where King John is rumoured to have signed the Magna Carta in 1215 (Bevan-Jones 2016). Other well-known trees include the Major Oak (Quercus robur) in Sherwood Forest, the most visited tree in the UK (Everett and Parakoottathil 2018) and associated with the story of Robin Hood; the most reliable estimates date it around 800 — 900 years old (Farjon 2017). Outside England, the 300-yearold Scottish Birnham Oak (Quercus petraea) is thought to be a relic of Birnham Wood, famously mentioned in Shakespeare's Macbeth (Woodland Trust undated).

Ancient and ageing trees also offer insights into historical and cultural vegetation and land management techniques used in different areas, such as coppicing or pollarding (the periodic cutting of the trunk to just above ground level (coppicing) or breast height (pollarding), from which regrowth is harvested at intervals) (Rackham 1967, 1994; Fuller and Warren 1993; Petit and Watkins 2003). Both methods can produce stools (coppices) or trunks (pollards) of extreme ages (Lewington 2012) and their use varies spatially and temporally in the UK, and so can inform us about changes in management and landscaping practice (Read 2000; Barnes et al. 2017). Ancient trees can also be historical relics of boundaries, hedgerows, commons, ancient woodlands and forests, avenues and ancient burial grounds (Stahle 1996; Lonsdale 2013; Farjon 2017). Additionally, although many 
ancient or veteran trees are hollow, dead stumps or fallen branches can be used to show evidence of changes in temperature, water availability, disease outbreaks and mechanical damage over time (Kelly et al. 1992; Briffa 2000; Cherubini et al. 2002; Ballesteros et al. 2010). Finally, ancient and ageing trees are not only relics of the past, but also important genetic resources for the future (Read 2000; Lonsdale 2013). These trees may harbour genes for pathogen resistance or stress tolerance (Major 1967), which we might consider exploiting when planting the next generation of veteran and ancient trees.

\section{Threats to ancient and ageing trees and associated organisms}

Ancient and veteran trees are in global decline, with losses reported in Australia (Fischer et al. 2010), America (Gibbons et al. 2008), South America (Laurance et al. 2000) and Europe (Linder and Östlund 1998; Jönsson et al. 2009). The key threats to the persistence and future of ancient tree populations are the lack of appropriate tree planting ( Read 2000) and elevated mortality (Gibbons et al. 2008; Le Roux et al. 2014) resulting from poor management of the trees e.g. the end of traditional techniques such as coppicing and pollarding (Lonsdale 2013), urbanisation, and the intensification of agricultural practices (Read 2000; Fay 2004; ATF 2005). There is also uncertainty around how ancient and veteran trees and their dependent species will be affected by climate change (Ranius 2002, 2006; Jonsson et al. 2005; ATF 2008a, b). Although ancient trees have shown their ability to survive over many centuries, they may be less able to cope with the rapid environmental and climate changes predicted in the future (Butler et al. 2002; ATF $2008 \mathrm{a}, \mathrm{b})$. A further impact of climate change and globalisation is the spread of treeassociated diseases and pests (Brasier 1996; Holdenrieder et al. 2004; Morin et al. 2007). Diseases such as Ash dieback (Hymenoscyphus fraxineus) have had devastating impacts on UK trees since 2000 (Mitchell et al. 2014).

\section{Ancient and veteran trees in the UK}

The UK ancient and veteran tree population is of global renown and interest, and there is a large amount of information about certain aspects of the trees including their management and associated arboriculture practices (Read 2000; Fay 2002, 2004; Lonsdale 2013), particular sites with high numbers of ancient and ageing trees (Mountford and Peterken 2003; Read et al. 2010; Hall and Bunce 2011), particular genera such as Oak (Quercus) or Yew (Taxus) (Moir 2013; Farjon 2017) and their historic context in the UK landscape (Rackham 1986, 1994; Fulford 1995; Butler et al. 2002; Farjon 2017). Yet despite all this, there is still a lack of consensus and discussion about the large-scale abundance and distribution of ancient, veteran and other noteworthy trees in the UK.

Particular sites that are most well-known for harbouring ancient and veteran trees are wood pastures and historic parklands, including deer parks, Royal Forests and commons (Rackham 1986, 1994; Hartel et al. 2013; Farjon 2017). The UK in particular is thought to have some of the highest concentrations of wood pastures in Europe (Rackham 1994), possibly due to the continuity of land ownership (Butler et al. 2002): it is a recognised UKBAP priority habitat (BRIG 2011). Another habitat that might include large numbers of ancient trees is ancient woodland (woodland that has existed since at least the sixteenth century and therefore unlikely to be of plantation origin: Peterken 1977), yet this has undergone extensive conversion to plantation or other land uses across England and Wales since 1930, and was reported to cover a mere 2.6\% of land in 1992 (Spencer and Kirby 
1992). Ancient trees are also found within farmland, in urban areas, as landscape boundaries, in tree avenues, on church grounds, in hedgerows or orchards and on private land or gardens (Rackham 1994; Read 2000; Woodland Trust 2017b, a), yet little is known about the distribution or state of these trees.

Although there is still uncertainty about the overall distribution and condition of ancient and veteran trees, the UK has substantially more information than other countries due to the long-term collation of tree records in the Ancient Tree Inventory (ATI) (https://ati. woodlandtrust.org.uk/). Other ancient tree inventories do exist covering a variety of geographical areas around the world. These range from global databases such as 'Monumental trees' (https://www.monumentaltrees.com) containing $\sim 40,000$ large, tall, old or notable trees across the world, to more localised regional databases such as the Remarkable trees of the Brussels-Capital region (https://bomen-inventaris.irisnet.be) which contains around $\sim 5800$ records. Nevertheless, none come close to the size or detail of the ATI. With over 200,000 trees recorded to date (at the time of writing in July, 2020), the ATI provides an opportunity to extensively examine our current understanding of UK ancient and ageing tree distributions and condition.

In this review of the ATI, we aim to highlight the value of this citizen science recording scheme in the UK, and present a framework for recording and maintaining an ancient tree database which could be applied to other international ancient and veteran tree populations. We also want to emphasise the importance of large, citizen science databases such as this for research and conservation. We first outline the ATI recording process and structure of the data, and then we present the results of statistical analyses of the data in three sections, (1) current distribution and characteristics, (2) condition, threats and attrition and (3) recording and survey information and limitations.

\section{Methods}

\section{Description of the ATI and recording process}

This review describes data from the ATI provided by the Woodland Trust in late 2018 (accessed 17/12/18). The ATI began as the Ancient Tree Hunt in 2004 and was originally envisaged as a 5-year citizen science project between the Ancient Tree Forum (ATF), Tree Register of the British Isles (TROBI) and the WT, that encouraged the public to record and map ancient, veteran and notable trees. The success of the original project has resulted in its continuation to the present day (at the time of writing in July 2020) as the ATI and over 200,000 trees have been mapped with many more still being recorded each year. The project was intended to cover the UK, but a small number of records have also been collected across Ireland. The ATI encourages not only the location of trees to be recorded, but also information about their condition, accessibility, survey information and other characteristics (Table 2).

Any member of the public can upload a record to the ATI via an online database system, with the minimum requirement of information added about each tree being location, girth, species (if possible to identify) and access information. Currently $87 \%$ of records have completed information for all categories. The WT recording protocol requires all uploaded records to undergo a second verification step, whereby trained WT verifiers revisit each tree to confirm the record, location and associated information. Additionally, a tree can only be classified as ancient, veteran or notable by a verifier. The ATI is actively managed as an online database by the WT, and a record can only be viewed by all members of the 
Table 2 Information collected about each Ancient Tree Inventory (ATI) record

\begin{tabular}{|c|c|}
\hline Field & Description \\
\hline Tree ID & A unique record ID \\
\hline Location & Grid reference (6-10 significant figures) \\
\hline Country & Country of tree \\
\hline County & County of tree \\
\hline Tree Site & Site name of record \\
\hline Public Accessibility & Information about tree access \\
\hline Location access comments & Information about accessibility and site \\
\hline Woodland Trust Wood & Whether the tree falls within Woodland Trust owned wood \\
\hline Category & Ancient, veteran or notable \\
\hline Veteran characteristics & Additional information about veteran characteristics of the tree \\
\hline Local historic name & Name of tree in local or national context \\
\hline Tree Form & Tree form and management status e.g. maiden, pollard etc \\
\hline Standing status & Whether the tree is standing or fallen \\
\hline Living status & Whether the tree is dead or alive \\
\hline Measured girth (m) & Measured girth of tree at breast height $(\sim 1.5 \mathrm{~m})$ \\
\hline Height of girth measurement (m) & Height that girth was measured from the ground \\
\hline Taxon & Taxonomic identity \\
\hline Image & Possibility to upload an image of the tree \\
\hline Date & Date the record was uploaded to the ATI \\
\hline Organisation & Organisation or individual who has uploaded the record \\
\hline Verification & Whether the tree has been verified by a Woodland Trust verifier \\
\hline Rating & Star rating of record \\
\hline Additional Notes & Additional notes about location, status and access \\
\hline
\end{tabular}

public once verified. The verification process is ongoing, so although not all trees in the ATI have currently been verified, they will be in the near future.

For guidance on how to distinguish between ancient, veteran and notable trees, verifiers are encouraged to refer to the WT's Ancient Tree Guide No. 4 (ATF 2008a, b) or to the WT website (https://ati.woodlandtrust.org.uk/what-we-record-and-why/what-we-record/). These sources describe in detail the features of each type of tree, as well as providing species-specific estimates of girth measurements for trees in each category. Verifiers are also required to attend an additional training day where they receive further guidance and assistance in distinguishing between the three categories.

In addition to members of the public, many organisations contribute to the ATI and also support, provide advice and campaign on behalf of ancient trees in the UK including the WT, Natural England, Scottish Natural Heritage, the National Trust, the ATF and the Royal Society for the Protection of Birds. Many of these organisations own and manage land containing ancient trees and all are vocal advocates of the importance of ancient trees. 


\section{Statistical analyses used to describe the ATI}

Multinomial logistic regression models were fitted to the ATI data to compare between ancient, veteran and notable tree categories in relation to three predictors (country, tree form and girth) including all second-level interactions. Models were fitted using the $\mathrm{R}$ package 'nnet' (Venables and Ripley 2002). The most parsimonious model was selected based on multidirectional stepwise regression using the Akaike Information Criterion (AIC) and parameter significance was assessed using Analysis of Variance (ANOVA) Wald Chi-Squared tests. Two models were fitted, one using all ATI records, and another using only records from the 12 most common tree genera. The latter model also included genera as an extra predictor. In addition, to describe patterns of variation in the relative frequency of trees in other categories where the information is not necessarily recorded for all trees (as with habitat and threats to each tree), we used independent Chi-Squared tests of association based on the absolute numbers of records. Finally, Pearson correlation coefficient tests were used to describe trends in data recording and girth measurements over time. Since some of these tests involved repeated analysis of the same variables, it is important to note that their results are not statistically independent; they provide a descriptive analysis of the data and should not be viewed as definitive tests of particular hypotheses about the association between variables in the ATI. All statistical analyses and modelling were carried out in R (R Core Team 2018).

\section{Results and discussion}

\section{Current distribution and characteristics}

\section{Location, category, taxonomy, tree form and girth}

There are 169,967 trees across the UK recorded in the version of the ATI used for this review (Fig. 1). The majority (83.1\%) are in England, with smaller numbers of records in Scotland (8.4\%), Wales (5.3\%), Northern Ireland (3.2\%) and Republic of Ireland (0.02\%). There are 15 records from Jersey, Guernsey and the Isle of Man. Records show a strong geographical bias towards southern English counties, with Berkshire (15,187 records), Herefordshire (10,934 records) and Wiltshire (9077 records) contributing a combined total of $20.7 \%$ of all records (Fig. S1). However, this is influenced by the high number of veteran and notable tree records in these areas; when considering only ancient trees, North Yorkshire and Cumbria become the second and third highest contributors, highlighting the importance of distinguishing between true ancient trees and those in other categories (as defined in Table 1). Like many of the patterns in the ATI data, these geographical biases may reflect recorder bias, as well as biological and historical processes which influence the distribution of ancient trees. The possible nature of the bias is discussed further in the 'Limitations of the ATI recording process' section and methods for quantifying and removing it are being actively explored (Nolan et al. unpubl.).

The majority of the trees in the ATI are veteran (103,648 records) or notable $(45,618$ records), with relatively few recorded as ancient (13,476 records) (Fig. 1). 6867 records have no category i.e. have not yet been verified or the category is unknown, the majority of which fall within N. Ireland. Eighty two of the trees are also listed as heritage trees and 31 as champions. Many trees have saproxylic organisms present on them (noted in their records), including ferns (3389 records), lichens (36,240 records), moss (31,253 records) 

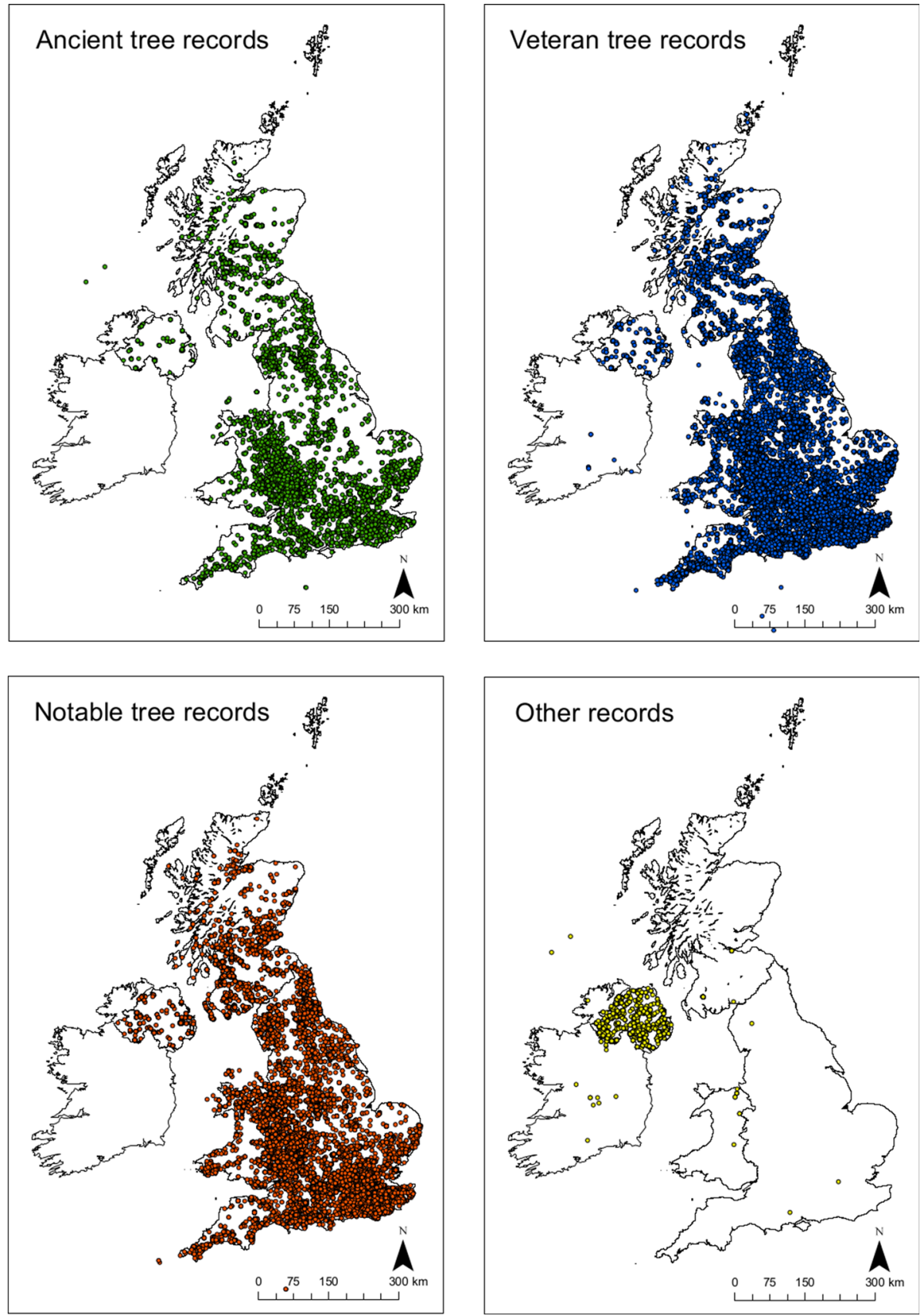

Fig. 1 Distribution maps of ancient, veteran, notable and other records in the ATI across the UK and Ireland. Several records have incorrect grid references in the ATI and therefore do not display in the correct location e.g. outside the UK boundary 
and several fungi species (Table S1). Although interesting, these observations are not necessarily the most informative, as quite young and small trees may have some moss or lichen. There is also likely to be inevitable bias in the recording and noting of these, depending on the recorders expertise, accessibility, habitat type etc. However, having the option to record locations and information about rare or endangered saproxylic species if found, in the ATI, could be valuable for other conservation purposes and projects.

Two hundred and eleven different taxa have been recorded in the ATI, ranging from family to species level including sub-species, cultivars and hybrid species (Table S2). The most common level of identification is genus (81,255 records), so further analysis in this report will focus only on this taxonomic rank. Quercus (Oak) is by far the most common genus recorded across the UK, representing almost half of all records (44.2\%), followed by Fagus (Beech) with 12.4\% and Fraxinus (Ash) with 6.9\%. The 12 most common genera contain $86.4 \%$ of all ATI records between them (Fig. 2).

Strong significant associations were found using multinomial logistic regression models between country, tree form, measured girth, genus and all second level interactions, across the three categories of trees (ancient, veteran and notable) (Table 3). When comparing across countries, there are proportionally more ancient tree records in Scotland and Wales than veteran or notable, and proportionally more notable tree records in Ireland (Fig. 3a). Tree form can be a key method in determining whether a tree will survive into its ancient phase. The aim of traditional management tools such as pollarding or coppicing was to extend a tree's life to exploit its resources, and consequently these techniques often produced trees that are many centuries old. Unsurprisingly therefore, there is a significant association between tree form and category (Table 3), with strong links between ancient

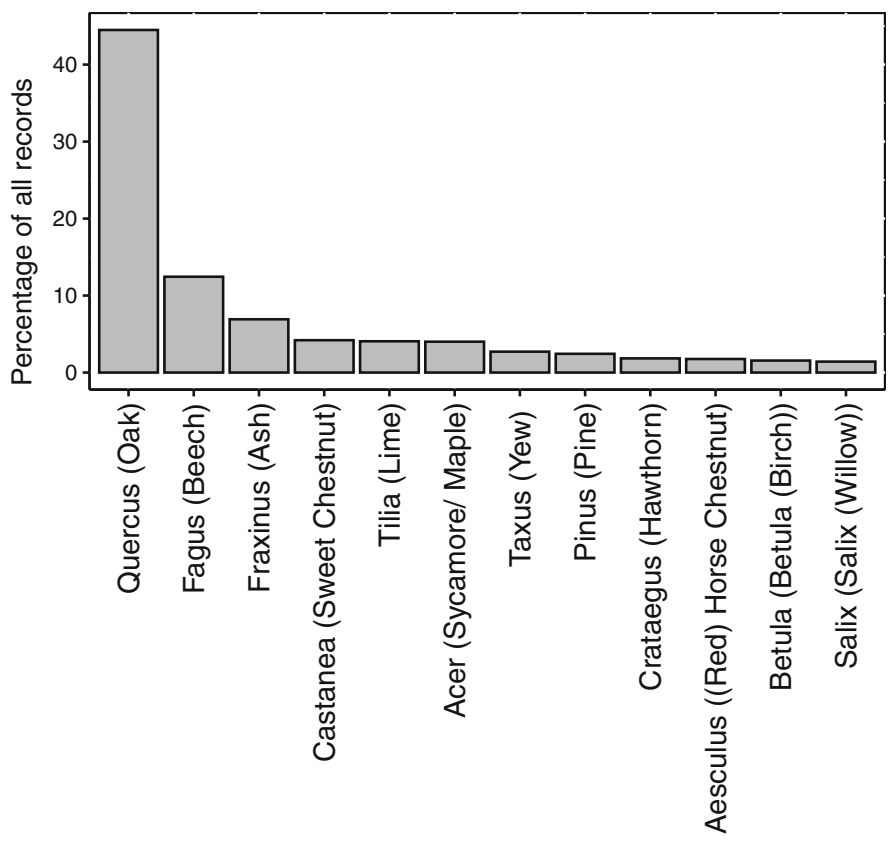

Genus

Fig. 2 The percentage contribution of the 12 most common genera to the total number of records in the ATI. The common name(s) of the species present in the ATI that fall within each genus is shown in brackets 
Table 3 Wald Chi-Squared Analysis of Variance (ANOVA) results to test parameter significance from a multinomial logistic regression model of category (ancient, veteran and notable tree) in relation to ATI characteristics

\begin{tabular}{llc}
\hline Predictor & All ATI records & Records from the 12 most common genera \\
\hline Country & $1194.6(8)^{* * *}$ & $897.7(8)^{* * *}$ \\
Girth & $14,104.9(2)^{* * *}$ & $20,926.5(2)^{* * *}$ \\
Tree Form & $12,930.4(14)^{* * *}$ & $11,768.3(14)^{* * *}$ \\
Country: Girth & $1704.7(8)^{* * *}$ & $383.9(8)^{* * *}$ \\
Country: Tree Form & $1276.2(56)^{* * *}$ & $567.8(56)^{* * *}$ \\
Girth: Tree Form & $1006.1(14)^{* * *}$ & $1334.3(14)^{* * *}$ \\
Genus & - & $6735.0(24)^{* * *}$ \\
Genus: Girth & - & $766.1(24)^{* * *}$ \\
Genus: Tree Form & - & $2186.9(168)^{* * *}$ \\
Genus: Country & - & $1880.0(96)^{* * *}$
\end{tabular}

Two models are fitted, one using all ATI records, and one using only records from the 12 most common genera of tree. The latter model also includes genus as a predictor and second level interactions of genus with the other predictors. Chi-Squared values (d. f.) and parameter significance are shown $(*<0.05$, $* *<0.01, * * *<0.001)$

and veteran trees and pollard form (Fig. 3b, c). However, only $6 \%$ of all pollards in the ATI are recorded as being actively managed; this raises concerns about the future survival of the high number of lapsed pollards throughout the landscape.

Ancient trees are also proportionally present more frequently as hedgerow trees or coppards (where the tree is cut at a height intermediate of a coppice and pollard), whereas veteran trees are proportionally more frequently found in other tree forms, and notable trees as maidens or coppices (Fig. 3b). However, it is important to note that the definition of a coppard has been revised by the Woodland Trust since this analysis was undertaken; due to the rarity of finding a true coppard, coppards are most likely now recorded as coppices or another tree form. Therefore, inferences about this finding should be taken with caution, as many of these coppard trees may in fact be lapsed coppices rather than true, actively managed coppards.

There were also significant differences between category across tree form and country (Table 3), with ancient trees proportionally more common than veteran and notable trees as pollards, hedgerow trees and coppards in England, but more common as pollards or other tree forms in Wales, and coppices, pollards or stumps in Scotland (Fig. 3c). Notable trees were most frequently found as maidens in all countries compared to ancient and veteran trees, but presented stronger associations with coppice and multi-stem tree form in England and Scotland than the other categories. Veteran trees showed proportionally stronger associations with other tree forms in both England and Scotland than the other categories, and in general were found in intermediate proportions between ancient and notable category across all tree forms and countries (Fig. 3c).

Tree form, country and girth also differed significantly between categories in relation to genus (Table 3). The most notable associations were between ancient tree category and Taxus (Yew), Castanea (Sweet Chestnut) and Fraxinus (Fig. 4a). Crataegus (Hawthorn) had the strongest association with veteran tree form, and Aseculus (Horse Chestnut) with notable tree form. The trees most likely to be recorded as coppices belong to Fraxinus or Acer (Maple) (Fig. 4b), particularly in relation to notable trees (Fig. S5), and pollards to 
(a)

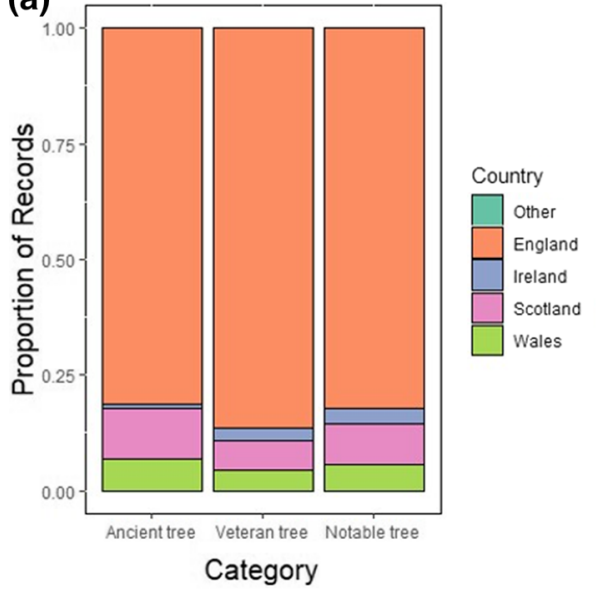

(b)

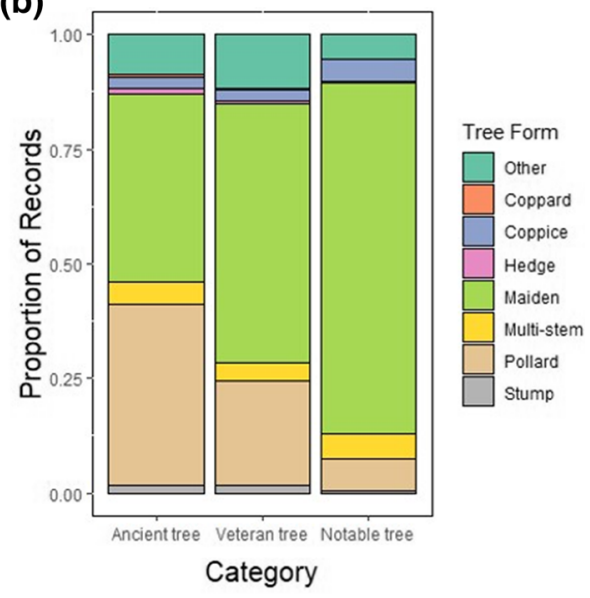

(c)
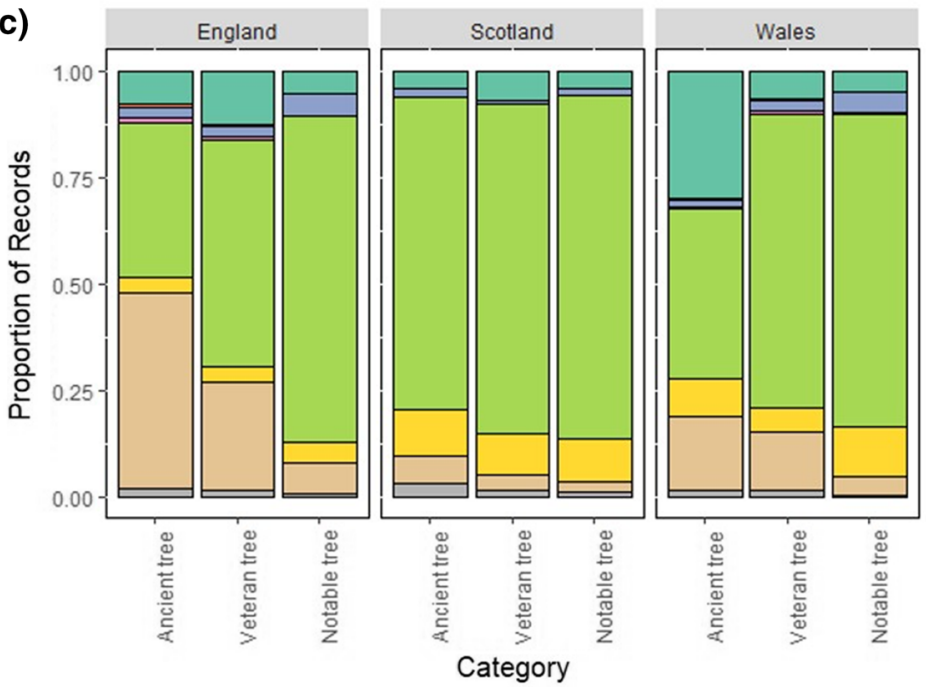

Tree Form

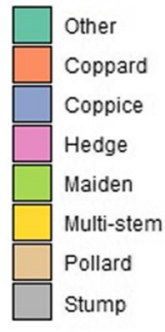

Fig. 3 The relative proportion of ATI records between three tree categories (ancient, veteran and notable) shown across a country of record, $\mathbf{b}$ tree form and $\mathbf{c}$ both country (England, Scotland and Wales) and tree form

Fraxinus, Quercus or Salix (Willow) (Fig. 4b), especially when in ancient form (Figure S5). Other notable associations include ancient Fagus trees and hedgerow or stump form, Taxus or Crataegus with multi-stem form, and Pinus, Castanea and Aesculus with maiden form (Figs. 4b, S5).

There is much discussion about the accuracy and usefulness of the relationship between tree girth and age, and without dendrochronological sampling a tree's age is often over or under-estimated (Hartesveldt et al. 1975; White 1998; Moir 2013). The age-diameter relationship has also been shown to vary depending on environmental parameters such as temperature and water runoff (Rohner et al. 2013) and across species (Yunyun Hi et al. 2009). Nevertheless, it is an important characteristic to record and can provide some 

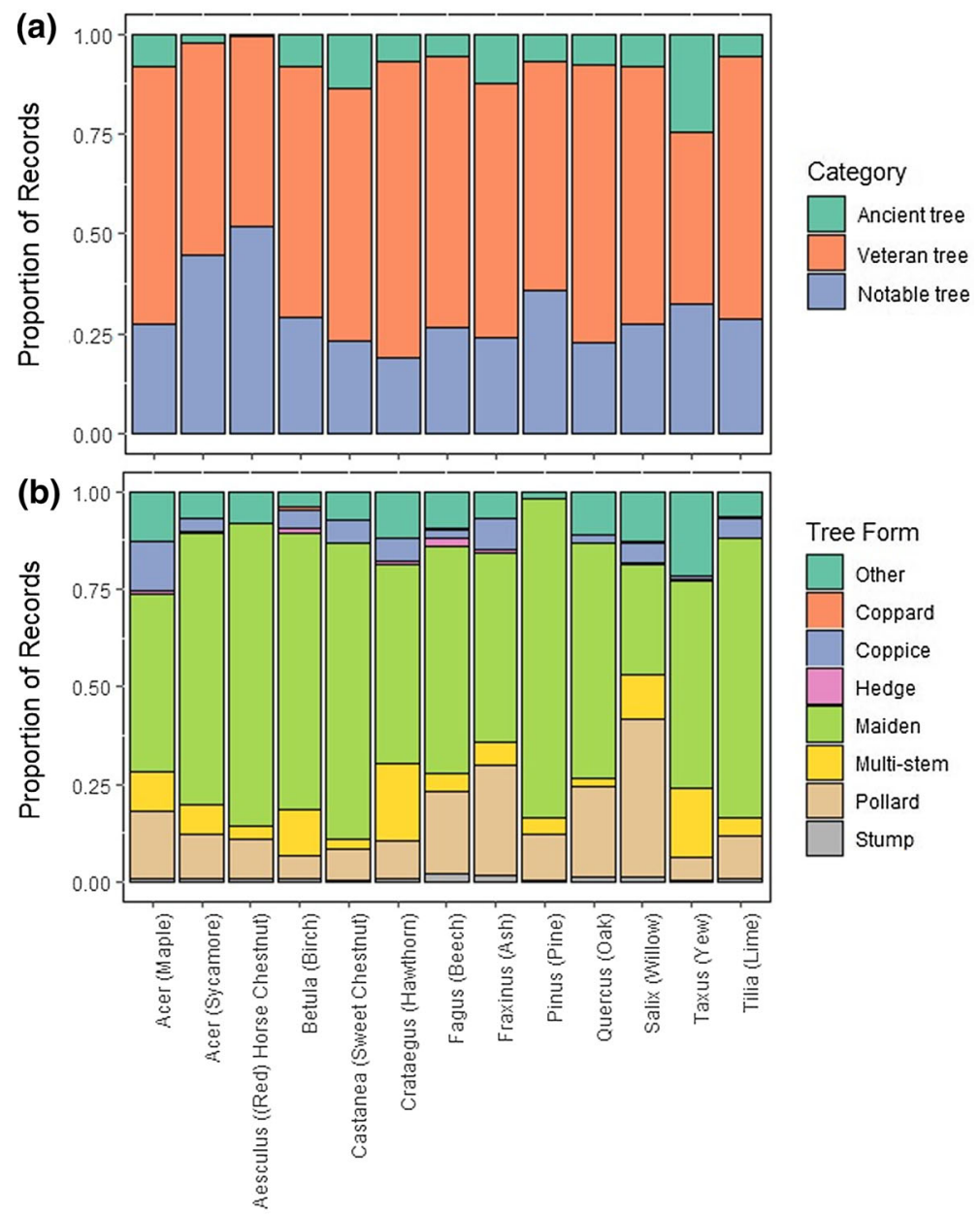

Genus

Fig. 4 The relative proportion of ATI records between a the three tree categories (ancient, veteran and notable) and the 12 most common genera and b the 12 most common genera and tree form. Although Sycamore and Maple belong to the same genus, they are shown separately here to identify any unique associations that may be present

general idea of the rough age of a tree (White 1998). Tree girth is usually measured at breast height ( $\sim 1.5 \mathrm{~m}$ above the ground) where possible, although this can be difficult for trees in pollard, coppice or multi-stem form. The mean height at which girth is measured for all ATI records is $1.573 \mathrm{~m}$.

There are 22 trees with measured girths greater than $20 \mathrm{~m}$ in circumference $(6.4 \mathrm{~m} \mathrm{dbh})$, with the largest (a maiden Pedunculate Oak), recorded as $54.18 \mathrm{~m}(17.2 \mathrm{~m} \mathrm{dbh})$ in girth. Most of these can be attributed to recording errors by the volunteers or verifiers i.e. omission of a decimal place; the largest Oak to ever be recorded is thought to be the Marton Oak in Cheshire (13.38 m girth, $4.26 \mathrm{~m} \mathrm{dbh}$ ) (Farjon 2017). Additional errors also occur when a recorder or verifier incorrectly identifies a cluster of trees or coppices as one multi-stem tree, therefore introducing erroneous inflated girth measurements into the ATI. 
To reduce the influence of these potentially biased records, only trees with girths below $15 \mathrm{~m}$ in circumference $(4.8 \mathrm{~m} \mathrm{dbh})$ were included in these analyses. An interesting initial observation is that there is a weak significant positive correlation between measured girth and date of record $(r=0.042, p<0.001)$, suggesting that there are many large, and potentially old, trees still being discovered.

Mean measured girth differed significantly across category, tree form and country (Table 3). As might be expected, ancient trees have larger girths in general than veterans, which in turn are larger than notable trees (Fig. 5). The largest mean girth measurements belonged to Welsh ancient trees in the form of coppards, pollards or other tree forms, English ancient trees in the form of hedgerow trees or coppices and Irish ancient coppice trees (Fig. 5). The largest veteran trees were Irish coppards or multi-stem trees, English veteran hedgerow trees or maiden trees in other locations (Jersey or Guernsey). In general, mean measured girth was smaller across Scotland than any other country.

Mean measured girth also differed significantly among the 12 most frequent genera in the ATI (Table 3; Fig. S4). The genus Castanea has by far the largest mean girth $(4.87 \mathrm{~m})$ followed by Taxus $(4.10 \mathrm{~m})$ and Quercus $(3.95 \mathrm{~m})$. Pinus, Betula and Crataegus all have relatively smaller girths. Quercus is often thought of as the typical 'ancient tree', especially in England (Farjon 2017), but surprisingly, Quercus spp. in the ATI had relatively smaller girths compared to other species than might be expected, which may be explained by the strong association of Oak with veteran rather than ancient form; as expected, veteran trees have significantly smaller girths than ancient trees. Oak was traditionally the preferred timber tree and its prevalence across the landscape is more due to economic factors than ecology (Williamson et al. 2017). When managed as a maiden tree, Oak was often harvested before reaching its mature phase, so was unlikely to reach great ages (Williamson et al. 2017). Most ancient Oaks remain today in either pollard or coppice form, or as maidens within parkland or wood-pasture (Farjon 2017). This may also be the case with Castanea (Sweet Chestnut) and Fraxinus, both of which have strong historical association with coppicing or pollarding practices (Williamson et al. 2017).

\section{Local habitat and site associations}

An interesting component of the ATI is the optional recording of habitat information for trees. Although only 69,308 (40.8\%) records have this information recorded, it offers

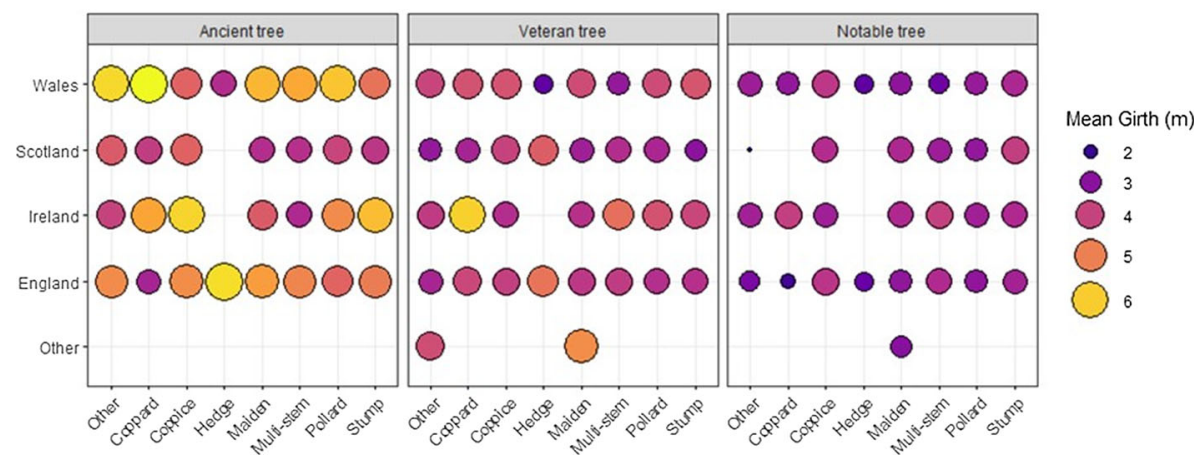

Fig. 5 Mean measured girth $(\mathrm{m})$ of trees recorded in the ATI shown for three tree categories (ancient, veteran and notable) across country and tree form of record. The larger the circle and the lighter the colour, the larger the mean measured girth 
insight into local habitat associations of trees. The number of records with habitat information is higher for ancient trees (47.9\%), compared to veteran (44.2\%) and notable trees $(36.3 \%)$. It also varies across country, ranging from $24.5 \%$ of records in Scotland to $61.9 \%$ of records in N. Ireland. The distribution of records is unequal across habitat types with $29.3 \%$ of records associated with woodland, $16.5 \%$ associated with parkland and $10.1 \%$ associated with field habitat. All other records fall within other habitat types (Fig. S2).

Habitat associations depend significantly on genus $\left(\chi^{2}=29,998\right.$, d.f. $\left.=132, p<0.001\right)$ (Fig. 6), with combinations of Tilia (Lime) in avenue habitat, Taxus in churchyards or cemeteries, Betula and Pinus in upland or moorland habitat, Fagus in woodland and Fraxinus in field habitat all appearing more frequently than expected. As with Taxus spp. in churchyards, Tilia spp. (Lime) are familiar elements of avenues, especially on historic estates and parkland (Pigott 1992; Couch 2012). Although abundant across much of the UK, Lime trees were favoured for avenues and parkland due to their aesthetically pleasing, tall and long-lived characteristics (Helliwell 1989). Both Betula (Birch) and Pinus (Pine) are common upland tree genera, especially in parts of Scotland (Fenton 1984) and Birch was heavily coppiced in these areas (Williamson et al. 2017). There are fewer strong negative associations, but Quercus spp. are present less frequently as avenue trees or in upland/moorland areas, Tilia spp. are less frequently present in woodland and Fagus spp. are less frequently present within field habitat than expected.

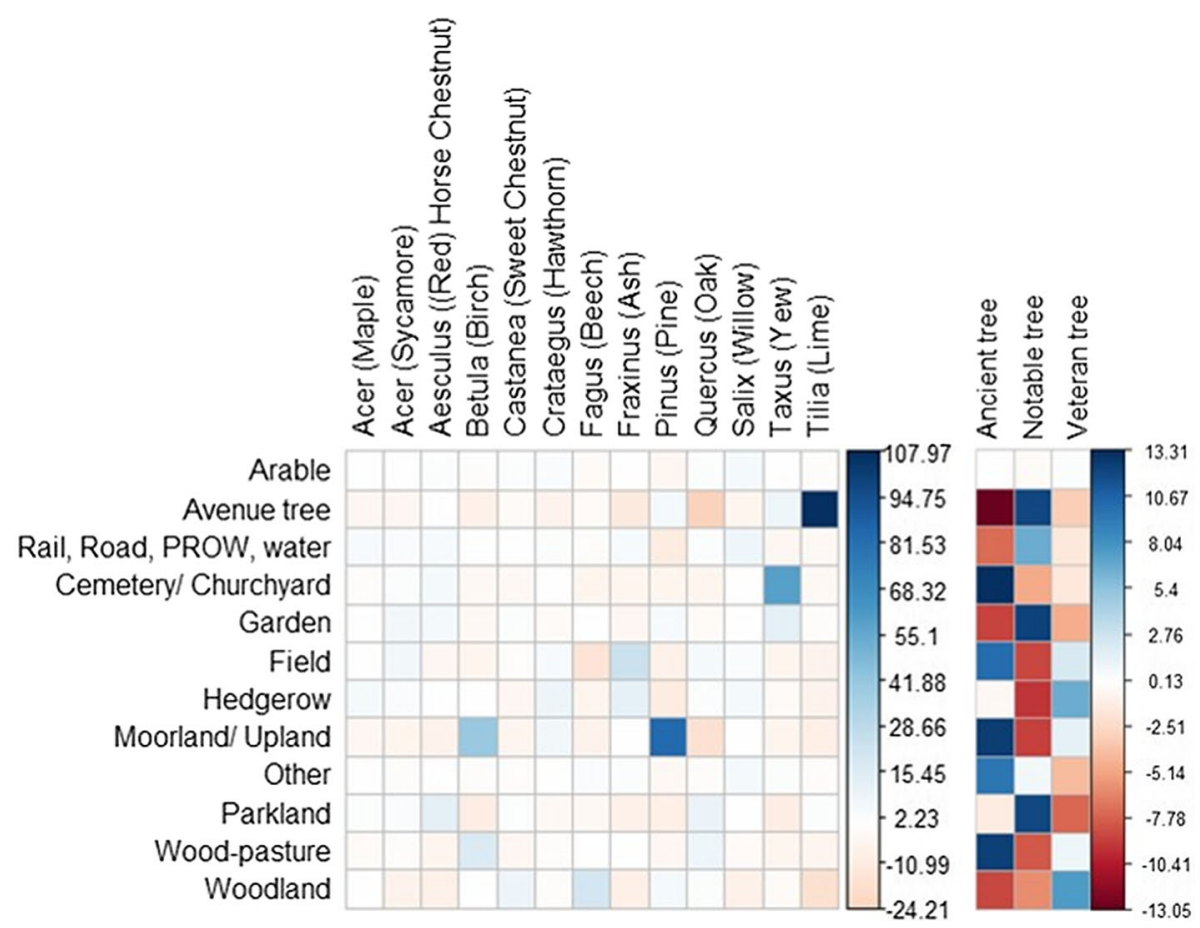

Fig. 6 Standardised Pearson residuals (r) from the Chi-Squared test of association between habitat and the 12 most common genera (left) and ancient, veteran or notable category (right) in the ATI. The higher the absolute residual value, the more that association contributes to the Chi-Squared statistic. Although Sycamore and Maple belong to the same genus, they are shown separately to identify any unique habitat associations that may be present 
Ancient, veteran and notable trees also have significantly different habitat associations $\left(\chi^{2}=2163.7\right.$, d.f. $\left.=22, p<0.001\right)$ (Fig. 6). Key habitats for ancient trees include cemeteries or churchyards, wood-pasture, fields and moorland or upland. Ancient trees are less likely to be present as avenue trees, in gardens, alongside roads, railways or other public rights of way, or in woodland. Veteran trees are also found less frequently than expected in parkland, gardens and avenues, but do have strong positive associations with woodland habitat and hedgerows. In contrast, notable trees follow opposite patterns to ancient or veterans and are more likely to be associated with avenues, gardens, parkland and public rights of way, and less likely to be found in hedgerows, fields, moorland or upland habitat, wood-pasture or woodland.

Where possible, recorders are encouraged to name the site on which a tree is found, and as a result, 69,308 trees can be located to 1466 specific named land areas. As with habitat, records appear biased towards public parks, large estates and historic forests, with the top 20 named sites (most of which fall into one of these three categories) containing $21.9 \%$ of all records between them (Fig. S3). Additionally, certain land owners have contributed heavily to the ATI, with 2925 records appearing on WT owned land across the UK. Separate analysis using publicly accessible National Trust databases across England (National Trust open data: 'limited access land' and 'always open land', accessed 08/01/ 19) shows that approximately $11.5 \%$ of all English ATI records fall within National Trust land. Churchyards and cemeteries also feature heavily, and contain $38.5 \%$ of all trees found on a named site. As before, these patterns probably reflect a combination of recorder bias and biological and historical processes, so further analysis might reveal interesting details for the understanding and conservation of ancient trees across the landscape.

By assessing the distribution of records across different scales (from country to individual site or habitat), we can gain insight into suitable locations for the persistence and survival of ancient trees to inform conservation and management action. Additionally, areas with few records, through either a lack of ancient trees or lack of surveys, can be targeted for future surveys, verification work or tree planting. The current distribution maps show records heavily clustered in southern English counties around London. These counties have strong associations with historic Royal forests, hunting grounds and private parks such as Richmond Park or Epping Forest (Farjon 2017). Similarly, Savernake forest, Windsor Great Park, Ashridge Estate and the New Forest (the four sites with the highest record abundance) currently are or have been owned at some point by the monarch. The continuity of the monarchy and aristocracy in the UK, unlike other European countries such as France and Germany, is likely to be one of the main influences on the high abundance of UK ancient trees (Rackham 1976; Butler et al. 2002; Farjon 2017).

\section{Condition, threats and attrition}

\section{Standing status and threats}

The standing and living status of each tree provides valuable information about the current condition, threats and attrition of ancient trees in the UK. In this version of the ATI (December, 2018) most trees (93.4\% of ancient trees, $95.7 \%$ of veteran trees, $98.3 \%$ of notable trees) are recorded as alive and standing. Only one tree is suffering from suspected Ash dieback and 15 trees are suffering from acute Oak decline or chronic Oak decline. However, this is very likely linked to observer bias; diseases such as Ash dieback are relatively difficult to spot in ancient trees, and so the total affected numbers are likely to be 
much higher. Additionally, there is likely to be a bias towards the recording of living (and therefore healthy) trees, as opposed to those that are fallen or dead, which may explain the low prevalence of diseased and dead trees in the ATI. Furthermore, most records have not been revisited since their initial recording, which for some trees is almost 16 years ago, so it is likely that some trees have subsequently been lost. Inferences about threats and disease should therefore be considered as speculative and a likely underestimation of the true, current status and attrition rate of ancient trees.

There is an additional option in the ATI to add information about apparent threats to trees, although this is highly likely to be biased by expertise in this area e.g. confident tree recorders such as arboriculturalists are much more likely to notice and record threats than the average ATI recorder. Therefore, any inferences about threats to particular trees should take into consideration potential recorder biases. 17,499 specific instances of a threat have been recorded that are tree-specific and include 'Compaction of root area' (31\% of threats), 'Grazing damage' (27\% of threats), 'Over shading' (15\% of threats), 'Major tree surgery' ( $8 \%$ of threats), 'Cultivation close to tree' (7\% of threats), 'Vandalism' (4\% of threats), 'Development or building' (3\% of threats), 'Vehicle damage' (3\% of threats) and 'Fire damage' ( $2 \%$ of threats).

Nevertheless, relatively few records have associated threats recorded (less than $10 \%$ of records are recorded as threatened) and there is no way to assess the completeness of this field, so it is likely that many more trees are threatened in some way. For example many other threats may be less observable to recorders such as nitrogen deposition and drought (Lindermayer et al. 2012; Lonsdale 2013). By understanding the individual age and species-specific threats, conservation work can be targeted in these areas to better protect the most vulnerable trees and ensure our current mature phase trees will reach their ancient phase and the continuity of deadwood habitats across the landscape. One obvious example is to promote continuous, appropriate management of coppices and pollards as part of any conservation plan for ancient trees.

There is a significant association between the 12 most frequent genera in the ATI and the type of threat $\left(\chi^{2}\right.$ test $=581.2$, d.f. $\left.=96, p<0.001\right)$ and also between the tree category and type of threat $\left(\chi^{2}=158.58, d . f .=16, p<0.001\right)$ (Fig. 7). Ancient trees are the most threatened category relative to veteran and notable trees, showing positive associations with six out of nine threats, the most prominent of which are grazing and fire damage, but also include cultivation, vandalism, tree surgery and development. Large, hollow trees are known to be vulnerable to fire. (Lanner 2002; Becker and Freeman 2009; Crane et al. 2017) especially in hot, arid places such as California or Australia (Lindenmayer et al. 2012). Although wildfires are infrequent and localised in the UK, fire damage through vandalism is a more common cause of ancient tree loss (Kirby et al. 1995). Over-grazing around ancient trees is also a common threat, due to the browsing of the bark, leaves or suckers from the tree, trampling of roots and high levels of excreted nutrients around the base of the tree (Manning et al. 2006; Hartel and Plieninger 2014). Veteran trees are very strongly impacted by over shading, and notable trees by cultivation and root compaction compared to other categories.

The greatest associations recorded between particular threats and genera are those between Fagus and over-shading, Taxus and tree surgery, Tilia, Aesculus and Pinus and grazing, and Pinus and root compaction. Quercus experiences the most threats relative to any other genera, showing strong associations with seven out of nine including vehicle damage, cultivation and root compaction, which is worrying as records of this genus comprise almost $50 \%$ of the ATI. The strong anthropogenic interest in old trees, especially old Oaks can sometimes be counter-productive: excessive, inappropriately managed 


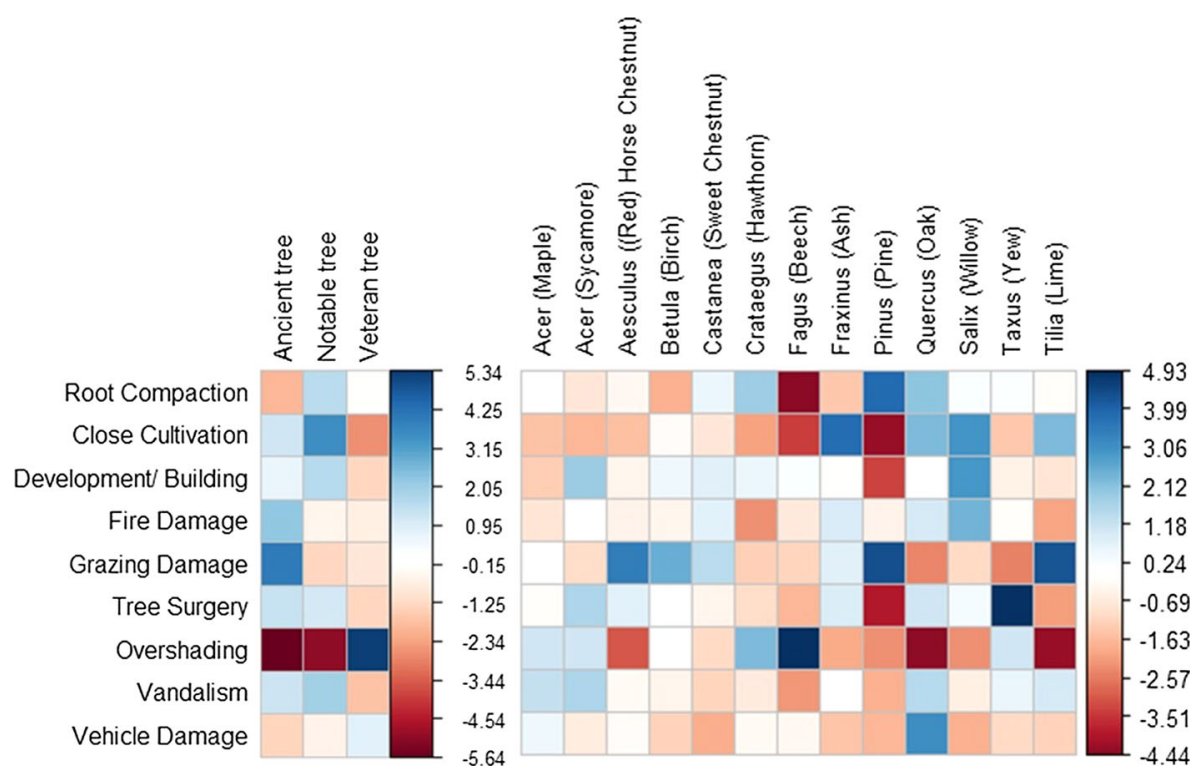

Fig. 7 Standardised Pearson residuals (r) from the Chi-Squared test of association between threat type and ancient, veteran or notable category (left) and the 12 most common genera (right) in the ATI. The higher the absolute residual value, the more that association contributes to the Chi-square statistic. Although Sycamore and Maple belong to the same genus, they are shown separately to identify any unique habitat associations that may be present

visitation to sites such as National Trust parklands or historic houses can result in pressure on exposed, scattered old trees. Conservation measures such as fencing can help to protect ancient trees against threats from livestock, human influences and cultivation (Fischer et al. 2009).

Legal protection for trees with veteran characteristics in the UK has improved significantly in the past few years, and the recently published 2019 National Planning Policy Framework (NPPF) now recognises both ancient trees and ancient woodlands as irreplaceable habitat' (NFFP 2019). Other protective measures include Tree Protection Orders (TPOs) or legislation protecting other species or habitats such as bat roosts, designated sites, hedgerows, or scheduled ancient monuments (Read 2000). Nevertheless, all of these measures can be overridden for 'exceptional reasons' such as health and safety concerns or national infrastructure projects (Read 2000; NPPF 2019).

\section{Attrition rate over time}

The global decline of decaying and dead wood habitat is a growing issue, and it appears that UK ancient, veteran and notable trees are no exception. Dead wood in different forms within an ecosystem is an important resource for many organisms (Hjältén et al. 2007; Lõhmus et al. 2010; Svensson et al. 2016), so its removal is likely to have cascading impacts across rural landscapes. Ancient and veteran tree loss is also hugely detrimental for wildlife and biodiversity in urban environments (Stagoll et al. 2012). Le Roux et al. (2014) predicted declines in urban ancient and veteran tree populations of $87 \%$ over the next 300 years under current management strategies. These declines were not halted by 
increasing the recruitment rate of ancient trees, and under the worst management scenarios, urban ancient and veteran tree populations were predicted to disappear within 115 years (Le Roux et al. 2014). Development or building works were found to present significant threats to Acer (Sycamore) and Salix, two of the UK's most abundant urban tree genera. As information about urban tree populations is sparse, it is important to increase quickly our understanding of their abundance and distribution to prevent their decline and the loss of ecological functions.

Since 2004, 47 ancient, 227 veteran and 84 notable trees are recorded as lost. Although some trees are only discovered once they are lost i.e. as a stump or fallen tree, some of the lost trees were previously recorded as alive, and have been revisited over time and have had their records updated. There does not appear to be any geographical pattern to these lost trees, and their distribution reflects that of ancient, veteran and notable trees across the UK. There is no significant correlation between year and proportion of lost ancient tree records collected $(r=-0.0004, p=0.999)$, or proportion of lost notable tree records collected $(r=-0.725, p=0.814)$. However, there is a moderate positive correlation between year and proportion of lost veteran tree records collected $(r=0.582, p=0.023)$. The data suggest that the proportion of veteran trees recorded as lost has increased over the past 20 years, either through increased surveying of lost trees or through an actual increase in the number of trees that have been removed or damaged.

Although this information gives some insight into attrition rates, the interpretation of this is problematic because we don't know the total standing ancient, veteran or notable tree population sizes in the UK, or the rate at which new recruits are entering or leaving each population i.e. how many notable trees are becoming veteran, and how many veterans are becoming ancient. Therefore, it is hard to know whether rates of loss are typical, and hence whether they reflect a population-level decline. Nevertheless, the establishment of the ATI means that we now have the ability to monitor long-term changes in the size and demographic constitution of ancient, veteran and notable trees, so future investigation into attrition rates should be more informative and reliable.

\section{Recording and survey information}

A feature of the ATI that increases its usefulness beyond being a simple database of species occurrences, is the extra information collected about the recording and verification process, including accessibility of sites, recorder or organisation identity, date, verification status and rating. These factors allow more accurate assessment of record reliability before being added to the ATI, as well as more detailed assessment of recorder biases, which in theory should result in highly accurate distribution maps. We recommend both current and future citizen science projects to implement similar features in their recording process, as it should firstly allow assessment of the record reliability and secondly could help to establish a framework for a longer-term monitoring program of a particular species or ecosystem.

\section{Accessibility and recorder}

The majority of records are found on open access land where members of the public have unrestricted access (Fig. S6). Nevertheless, a remarkably high number of records $(37.5 \%)$ are found on private land, where there are no public footpaths, which is another important cause of spatial bias in the ATI. These records result mostly from pre-arranged site visits with consent from the landowner or site manager, and although more challenging to 
organise, they are useful in both obtaining ATI records and raising awareness of the importance of ancient trees on the site and within the wider landscape. The largest contribution of records $(13.1 \%)$ to the ATI comes from the collective input of individual members of the public, but an additional 101 charities, consultancies and conservation organisations have contributed records, the top 10 of which have recorded $55 \%$ of all records. Although most are national organisations and charities, several county-specific ancient tree-recording groups have made significant contributions.

\section{Date of tree record}

The ATI began in 2004 as the Ancient Tree Hunt, which is reflected in the sudden increase in the number of records in 2005. Records added before this date have come from original Tree Register of the British Isles records that had been collated over many years and provided the initial inspiration for the ATI. The earliest record is of an ancient Oak tree recorded in 1900 at Croft Castle, Herefordshire with a $7.63 \mathrm{~m}$ girth. The years following 2004 saw many more records added, even after the original project ended and the Ancient Tree Hunt became the ATI. However, in recent years (2011 onwards) there has been a decline in the number of records added each year, although 2017 proved a better year than the past five.

The number added in 2018 is very low due to the fact that the ATI online recording platform was being updated throughout the spring and summer period and was unavailable during this time. We expect to see a boost in records in 2019/2020 as trees recorded by volunteers in 2018 are retrospectively added to the ATI. Currently, the date associated with each record is its date of upload to the ATI website, so may not necessarily be the date a tree is recorded. The delay between the two processes can be lengthy (potentially several years difference), but due to the longevity of the trees this is unlikely to make a substantial difference to the overall distribution map, providing that the tree is not felled or damaged.

\section{Verification steps in the ATI}

Best practice is for each ATI record to be revisited by a WT verifier after it is uploaded, to confirm the tree's location and status and to maintain credibility of the ATI. Reassuringly, a high proportion of ATI records have been verified at least once, with some trees being revisited many times to assess their status and persistence. However, this proportion is slightly less for ancient trees $(97.7 \%)$ compared to veterans $(98.3 \%)$ or notables $(99.2 \%)$. Verification work in the first instance should be targeted at N. Ireland, where the highest percentage $(26.2 \%)$ of records are unclassified as ancient, veteran or notable, compared to $2.9 \%$ in England, 3.2\% in Scotland and $8.5 \%$ in Wales. Although most records have undergone this verification, there is concern that some have not and may therefore be incorrect.

As an extra step, each record has been provided with a star rating to reflect its validity and reliability (Table 4). This was determined by the Woodland Trust ATI managers and relates predominantly to the level of verification for each record. Citizen science programs can introduce more errors or bias than traditional scientific recording methods (Dickinson et al. 2010; Crall et al. 2011), but record verification by volunteers has been shown to be more cost-effective than traditional data collection by professional scientists and less errorprone than using unverified records (Gardiner et al. 2012). These extra steps should help identify and eliminate biased or false records in the ATI. 
Table 4 The ATI star rating system and the number of records within each group

\begin{tabular}{|c|c|c|c|}
\hline Rating & $\begin{array}{l}\text { No. of } \\
\text { records }\end{array}$ & $\begin{array}{l}\% \text { of } \\
\text { total }\end{array}$ & Reason for rating \\
\hline 5 & 77,767 & 45.75 & Recorded and verified by WT verifiers on site \\
\hline 4 & 46,087 & 27.12 & $\begin{array}{l}\text { Verified by a WT verifier or Quality Assured records but not verified } \\
\text { on site }\end{array}$ \\
\hline 3 & 30,932 & 18.20 & Verified by volunteers of another organisation \\
\hline 2 & 5905 & 3.47 & Data that has proved unreliable and unverified \\
\hline 1 & 9276 & 5.46 & Unverified but with potential of being 5 star \\
\hline
\end{tabular}

A potential improvement to the recording process could be the introduction of remote, online verification using the uploaded photos, which would increase the quantity of records that could be verified to a high standard providing that the photos are of a good quality. Throughout the project, there has been periodic background screening and revision of parts of the dataset carried out remotely by an expert head verifier and other trained volunteers, in order to increase the accuracy and robustness of the data. This usually includes running queries in the data to target records with missing information or fields with suspicious values. Nevertheless, not all records have received this extra attention due to the time consuming nature of this process and large quantities of records. Therefore, increasing the capacity and efficiency of this process, perhaps through additional 'lead' verifiers, or by encouraging the public to upload more photos of the trees, could increase the robustness of the data and the data-capturing process.

\section{Limitations of the ATI recording process}

Firstly, the confusion regarding the terminology of ancient and other noteworthy trees presents problems in understanding the true nature of each record. The classification of an ancient or veteran tree based on the presence-absence of 'veteran' characteristics is a reliable distinguisher from notable trees. However, the difference between an ancient and veteran tree is much more arbitrary, and likely to vary across recorder or verifier based on experience or geographical region. Additionally, comparisons between different studies on ancient trees, whether in the UK or between other international ancient tree populations, will be difficult if definitions are not standardised. Although the WT provide guidelines for tree age based on girth measurements per species (ATF 2008a, b), as mentioned previously, tree age is thought to vary hugely across different environmental conditions. Therefore, it is likely there are a number of ATI records that have been subjectively misclassified, and awareness of this issue is important when separating ancient trees from veteran trees for conservation purposes. Nevertheless, concentrating purely on trees displaying 'veteran' characteristics i.e. the characteristics most ecologically important for saproxylic organisms, mitigates this issue to a large extent until clearer definitions of ancient and veteran trees can be established.

Although the ATI is the most comprehensive database of ancient and ageing trees to date, it suffers many of the drawbacks of a citizen science recording program, including sampling bias. Sampling (or survey) bias results from the 'ad-hoc', non-representative recording method of public recording schemes and is often present in online, museum or herbarium datasets (Boakes et al. 2010; Rocchini et al. 2011). ATI recording and the 
subsequent distribution maps are likely to be strongly influenced by the home location of the most active recorders and WT verifiers, and accessibility to sites such as private estates and parks. For example, the majority of the top 20 named sites with the most trees are all large, well-known, accessible parks, so the high abundances in these areas may be from large numbers of visitors who simply enjoy visiting here. Similarly, the comparatively low number of trees in Northern Ireland and Ireland could be a result of a lack of recorders, or low levels of interest or awareness of the ATI. Recording is also likely to be biased towards areas with good coverage of public rights of way, footpaths and roads, so working with farmers and landowners, and raising awareness of the ecological benefits of ancient trees in the landscape could help gain access to sites for recording purposes.

There are currently a variety of statistical methods that are able to cope with large, biased species datasets, including spatial filtering of occurrence records, producing bias layers to capture the anthropogenic influence of recording or using statistical models to account for bias (Phillips et al. 2009; Fourcade et al. 2014; Boria et al. 2014; Bird et al. 2014). The ATI is unique in its abundance of unusually good information about recorder location and identity, so presents a brilliant opportunity for bias correction methods to be applied; this a focus for our current research (Nolan et al. unpubl.). Many citizen-science projects require recorders to provide an estimate of their level of expertise or education (Kosmala et al. 2016), which can greatly benefit scientific research based on these data (Johnston et al. 2018). Therefore, collecting more information about sampling effort, time spent in the field, number of volunteers and level of expertise in identification for each record would help to address the issues caused by these biases. In the meantime, identified patterns and conclusions drawn from information in the ATI should be considered in parallel to potential patterns of bias, and caution should be applied when using the ATI for ecological or conservation research without prior consideration of the data limitations.

The reliability of the grid references should be also questioned, as even though the majority are recorded with $1 \mathrm{~m}$ precision (10-figure grid references), or at the very least $100 \mathrm{~m}$ precision (6-figure grid reference), several records display outside of the UK boundary and are certainly incorrect. It is likely therefore, that there are other records within the UK boundary that are also incorrect. Increasing the number of trees that are revisited over the next few years will increase the accuracy of the ATI and ideally reduce the amount of false information, yet this may be difficult if an incorrect grid reference has been provided and there are many recorded trees on a site. WT verifiers are often familiar with the problem and the inclusion of an image of the tree mitigates it somewhat, nevertheless there are several thousand duplicated records in the ATI that have been recorded multiple times. Additional work to remove these records is being currently undertaken by WT staff members and other experienced individuals.

A possible remedy for the incorrect grid references could be the development of a smartphone app to collect high quality GPS location data, as well as provide a more accurate estimate of the time the tree is recorded. Many large citizen-science projects such as 'eBird', 'Project Noah or 'What's Invasive!' currently benefit from mobile-phone record collection methods (Graham et al. 2011; Teacher et al. 2013; Luna et al. 2018) and although not currently available for the ATI, a mobile app could be a valuable asset to the project for data acquisition. As mentioned previously, the ATI website was redeveloped in the summer of 2018, providing a more user-friendly interface, additional recording features such as the ability to update record information for previously recorded trees and a boost in marketing and awareness about the ATI. Therefore, we expect to see an increase in the number of records added in 2019/2020, and examining data for these years will allow us to further evaluate aspects of the ATI. 


\section{Conclusion}

Citizen science data i.e. data collected by members of the public, are usually stored in online databases, museums and herbariums, and are valuable resources of species records spanning large scales and long time periods. In ecology, conservation and biogeography, this type of data is often difficult to collect due to financial, geographical and time constraints, so public databases are useful sources of species data for scientific research (Schmeller et al. 2009; Devictor et al. 2010; Tulloch et al. 2013). The ATI provides substantial information about the distribution, condition and attrition of ancient, veteran and notable trees across the UK. Nevertheless, unlike other UK citizen science projects such as the British Trust for Ornithology's (BTO) Big Garden Bird Watch, or the UK Butterfly Monitoring Scheme, the ATI remains largely under-used and under-appreciated in the scientific community, despite its longevity and number of records. This is likely due to uncertainty regarding the reliability, usefulness and limitations of the ATI; issues that hopefully this review can identify and address. Therefore, although subsets of the ATI have previously been examined in detail, for example records of large ancient oaks (Farjon 2017), this review is the first attempt to summarise key information about all trees recorded in the ATI, and to provide a national overview of these ecologically, historically and culturally important organisms.

We highlight the importance of discussing ancient trees in their proper context, and making distinctions between ancient, veteran, notable and other types of old, large or noteworthy trees. This research also emphasises the differences between tree taxa, and the need to consider the habitat, threats and other characteristics for individual species or genera when planning appropriate management or conservation strategies. We have highlighted the importance of documenting ancient trees, and we present here a framework that could be adopted in other countries for the collection of robust and reliable data. The benefits of both expanding and maintaining databases such as the ATI to conservation and policy are invaluable for monitoring and protecting species worldwide.

Acknowledgements We would like to thank the Woodland Trust for their provision of the Ancient Tree Inventory data and their great help and advice in compiling this article. In particular we would like to thank Kylie Harrison-Mellor (now Natural England) and Jill Butler. This research was supported by the University of Nottingham and the Woodland Trust.

Open Access This article is licensed under a Creative Commons Attribution 4.0 International License, which permits use, sharing, adaptation, distribution and reproduction in any medium or format, as long as you give appropriate credit to the original author(s) and the source, provide a link to the Creative Commons licence, and indicate if changes were made. The images or other third party material in this article are included in the article's Creative Commons licence, unless indicated otherwise in a credit line to the material. If material is not included in the article's Creative Commons licence and your intended use is not permitted by statutory regulation or exceeds the permitted use, you will need to obtain permission directly from the copyright holder. To view a copy of this licence, visit http://creativecommons.org/licenses/by/4.0/.

\section{References}

Alexander K (1999) The invertebrates of Britain's wood pastures. Br Wildl 11(2):108-117

Ancient Tree Forum c/o The Woodland Trust (2005) Ancient Tree Guide No. 1: Trees and Farming. https:// www.woodlandtrust.org.uk/publications/2005/01/ancient-tree-guide-1/. Accessed 17 Oct 2017

Ancient Tree Forum c/o The Woodland Trust (2008) Ancient Tree Guide No. 5: Trees and Climate Change. https://www.woodlandtrust.org.uk/publications/2008/12/ancient-tree-guide-5/. Accessed 17 Oct 2017 
Ancient Tree Forum c/o The Woodland Trust (2008) Ancient Tree Guide No. 4: What are ancient, veteran and other trees of special interest? https://www.woodlandtrust.org.uk/publications/2008/11/what-areancient-veteran-and-trees-of-special-interest/. Accessed 17 Oct 2017

Ancient Tree Forum c/o The Woodland Trust (2011) Ancient Tree Guide No. 3: Trees and Development. https://www.woodlandtrust.org.uk/publications/2011/12/ancient-tree-guide-3/. Accessed 17 Oct 2017

Ballesteros J, Stoffel M, Bodoque J, Bollschweiler M, Hitz O, Díez-Herrero A (2010) Changes in Wood Anatomy in Tree Rings of Pinus pinaster Ait. Following wounding by flash floods. Tree-Ring Res 66:93-103. https://doi.org/10.3959/2009-4.1

Barnes G, Pillatt T, Williamson T (2017) Trees in England: management and disease since 1600. Univ of Hertfordshire Press, Hatfield

Becker N, Freeman S (2009) The economic value of old growth trees in Israel. For Policy Econ 11:608-615. https://doi.org/10.1016/j.forpol.2009.08.004

Bevan-Jones R (2016) The ancient yew: a history of Taxus baccata. Windgather Press, Devon

Bird T, Bates A, Lefcheck J, Hill N, Thomson R, Edgar G, Stuart-Smith R, Wotherspoon S, Krkosek M, Stuart-Smith J, Pecl G, Barrett N, Frusher S (2014) Statistical solutions for error and bias in global citizen science datasets. Biol Conserv 173:144-154. https://doi.org/10.1016/j.biocon.2013.07.037

Boakes E, McGowan P, Fuller R, Chang-qing D, Clark N, O'Connor K, Mace G (2010) Distorted views of biodiversity: spatial and temporal bias in species occurrence data. PLoS Biol. https://doi.org/10.1371/ journal.pbio. 1000385

Boddy L (2001) Fungal community ecology and wood decomposition processes in angiosperms: from standing tree to complete decay of coarse woody debris. Ecol Bull 49:43-56

Boria R, Olson L, Goodman S, Anderson R (2014) Spatial filtering to reduce sampling bias can improve the performance of ecological niche models. Ecol Model 275:73-77. https://doi.org/10.1016/j.ecolmodel. 2013.12.012

Brasier C (1996) Phytophthora cinnamomi and oak decline in southern Europe. Environmental constraints including climate change. Ann Sci For 53:347-358. https://doi.org/10.1051/forest:19960217

Briffa K (2000) Annual climate variability in the Holocene: interpreting the message of ancient trees. Quat Sci Rev 19:87-105. https://doi.org/10.1016/S0277-3791(99)00056-6

Biodiversity Reporting and Information Group (BRIG) (2011) UK Biodiversity Action Plan - priority habitat descriptions. JNCC, Peterborough

Butler J, Alex K, Green T (2002) Decaying wood: an overview of its status and ecology in the United Kingdom and Continental Europe. USDA For Serv Gen 181:11-19

Cherubini P, Fontana G, Rigling D, Dobbertin M, Brang P, Innes J (2002) Tree-life history prior to death: two fungal root pathogens affect tree-ring growth differently. J Ecol 90:839-850. https://doi.org/10. 1046/j.1365-2745.2002.00715.x

Cooke R (1984) Ecology of Saprotrophic Fungi, 1st Edition edition. ed. UK: Longman 1984.

Couch S (2012) Conservation of avenue trees. Arboric J 18:307-230

Crall A, Newman G, Stohlgren T, Holfelder K, Graham J, Waller D (2011) Assessing citizen science data quality: an invasive species case study. Conserv Lett 4:433-442. https://doi.org/10.1111/j.1755-263X. 2011.00196.x

Crane M, Lindenmayer D, Cunningham R, Stein J (2017) The effect of wildfire on scattered trees, 'keystone structures', in agricultural landscapes. Austral Ecol 42:145-153. https://doi.org/10.1111/aec.12414

Cusack C (2013) Scotland's sacred tree: the fortingall yew. J Syd Soc Scott Hist 14:106-120

Devictor V, Whittaker R, Beltrame C (2010) Beyond scarcity: citizen science programmes as useful tools for conservation biogeography. Divers Distrib 16:354-362. https://doi.org/10.1111/j.1472-4642.2009. 00615.x

Dickinson J, Zuckerberg B, Bonter D (2010) Citizen science as an ecological research tool: challenges and benefits. Annu Rev Ecol Evol Syst 41:149-172. https://doi.org/10.1146/annurev-ecolsys-102209144636

Everett S, Parakoottathil D (2018) Transformation, meaning-making and identity creation through folklore tourism: the case of the Robin Hood Festival. J Herit Tour 13:30-45. https://doi.org/10.1080/ 1743873X.2016.1251443

Farjon A (2017) Ancient Oaks in the English landscape. Kew Publishing, London

Fay N (2002) Environmental arboriculture, tree ecology and veteran tree management. Arboric J 26:213-238. https://doi.org/10.1080/03071375.2002.9747336

Fay N (2004) Survey methods \& development of innovative arboricultural techniques. The Trees of History, Proceedings of the International Congress; University of Torino, Italy

Fenton J (1984) The SWT Highland birchwood survey. Edinburgh: Scottish Ecological Consultants on behalf of Scottish Wildlife Trust.causing legal issues (ATF website, 2019). 
Fischer J, Stott J, Zerger A, Warren G, Sherren K, Forrester R (2009) Reversing a tree regeneration crisis in an endangered ecoregion. Proc Natl Acad Sci USA 106:10386-10391. https://doi.org/10.1073/pnas. 0900110106

Fischer J, Zerger A, Gibbons P, Stott J, Law B (2010) Tree decline and the future of Australian farmland biodiversity. Proc Natl Acad Sci USA 107:19597-19602. https://doi.org/10.1073/pnas.1008476107

Fourcade Y, Engler J, Rödder D, Secondi J (2014) Mapping species distributions with MAXENT using a geographically biased sample of presence data: a performance assessment of methods for correcting sampling bias. PLoS ONE. https://doi.org/10.1371/journal.pone.0097122

Fulford T (1995) Wordsworth's 'Yew-Trees': politics, ecology, and imagination. Romanticism 1:272-288. https://doi.org/10.3366/rom.1995.1.2.272

Fuller R, Warren M (1993) Coppiced woodlands: their management for wildlife. Joint Nature Conservation Committee, Peterborough

Gardiner M, Allee L, Brown P, Losey J, Roy H, Smyth R (2012) Lessons from lady beetles: accuracy of monitoring data from US and UK citizen-science programs. Front Ecol Environ 10:471-476. https:// doi.org/10.1890/110185

Gibbons P, Lindenmayer D, Fischer J, Manning A, Weinberg A, Seddon J, Ryan P, Barrett G (2008) The future of scattered trees in agricultural landscapes. Conserv Biol 22:1309-1319. https://doi.org/10. 1111/j.1523-1739.2008.00997.x

Gough L, Sverdrup-Thygeson A, Milberg P, Pilskog H, Jansson N, Jonsell M, Birkemoe T (2015) Specialists in ancient trees are more affected by climate than generalists. Ecol Evol 5:5632-5641. https:// doi.org/10.1002/ece3.1799

Graham E, Henderson S, Schloss A (2011) Using mobile phones to engage citizen scientists in research. Eos 92:313-315

Graves R (1948) The White Goddess: a Historical Grammar of Poetic Myth. Faber and Faber UK, London

Hageneder F (2007) Yew: a history. Sutton Publishing Ltd, Stroud

Hall S, Bunce R (2011) Mature trees as keystone structures in Holarctic ecosystems: a quantitative species comparison in a northern English park. Plant Ecol Divers 4:243-250. https://doi.org/10.1080/ 17550874.2011.586735

Hartel T, Dorresteijn I, Klein C, Máthé O, Moga C, Öllerer K, Roellig M, von Wehrden H, Fischer J (2013) Wood-pastures in a traditional rural region of Eastern Europe: characteristics, management and status. Biol Conserv 166:267-275. https://doi.org/10.1016/j.biocon.2013.06.020

Hartel T, Plieninger T (2014) European wood-pastures in transition: a social-ecological approach. Routledge, London

Hartesveldt R, Harvey H, Shellhammer H, Stecker R (1975) The Giant Sequoia of the Sierra Nevada. Rep. NPS 120, USDI National Park Service, Washington, DC.

Helliwell D (1989) Lime Trees in Britain. Arboric J 13:119-123. https://doi.org/10.1080/03071375.1989. 9756409

Hjältén J, Johansson T, Alinvi O, Danell K, Ball J, Pettersson R, Gibb H, Hilszczański J (2007) The importance of substrate type, shading and scorching for the attractiveness of dead wood to saproxylic beetles. Basic Appl Ecol 8:364-376. https://doi.org/10.1016/j.baae.2006.08.003

Holdenrieder O, Pautasso M, Weisberg P, Lonsdale D (2004) Tree diseases and landscape processes: the challenge of landscape pathology. Trends Ecol Evol 19:446-452. https://doi.org/10.1016/j.tree.2004. 06.003

Hooke D (2011) Trees in Anglo-Saxon England. Camb. Core. https://www.core/books/trees-in-anglosaxonengland/6E3D5569A08C32256D77AA9545D8C1FC. Accessed 19 July 2019

Humphrey J (2005) Benefits to biodiversity from developing old-growth conditions in British upland spruce plantations: a review and recommendations. For Int J For Res 78:33-53. https://doi.org/10.1093/ forestry/cpiO04

Johnston A, Fink D, Hochachka W, Keling S (2018) Estimates of observer expertise improve ecological inference from citizen science data. Methods Ecol Evol 9:88-97

Jonsson B, Kruys N, Ranius T (2005) Ecology of species living on dead wood: lessons for dead wood management. Silva Fennica 39(2):289-309

Jönsson M, Fraver S, Jonsson B (2009) Forest history and the development of old-growth characteristics in fragmented boreal forests. J Veg Sci 20:91-106. https://doi.org/10.1111/j.1654-1103.2009.05394.x

Kelly P, Cook E, Larson D (1992) Constrained growth, cambial mortality, and dendrochronology of ancient Thuja occidentalis on cliffs of the niagara escarpment: an eastern version of bristlecone pine? Int $\mathbf{J}$ Plant Sci 153:117-127. https://doi.org/10.1086/297013

Kirby K, Thomas R, Key R, McLean I, Hodgetts N (1995) Pasture-woodland and its conservation in Britain. Biol J Linn Soc 56:135-153. https://doi.org/10.1111/j.1095-8312.1995.tb01129.x 
Kosmala M, Wiggins A, Swanson A, Simmons B (2016) Assessing data quality in citizen science. Front Ecol Environ 14:551-560

Lachat T, Bouget C, Bütler R, Müller J (2013) Deadwood: quantitative and qualitative requirements for the conservation of saproxylic biodiversity. In: integrative approaches as an opportunity for the conservation of forest biodiversity. European Forest Institute, Joensuu pp 92-102

Lanner R (2002) Why do trees live so long? Ageing Res Rev 1:653-671. https://doi.org/10.1016/S15681637(02)00025-9

Laurance W, Delamônica P, Laurance S, Vasconcelos H, Lovejoy T (2000) Conservation: rainforest fragmentation kills big trees. Nature 404:35009032. https://doi.org/10.1038/35009032

Lewington A (2012) Ancient trees: trees that live for a thousand years. Pavilion Books, London

Lindenmayer D, Laurance W, Franklin J (2012) Global decline in large old trees. Science 338:1305-1306. https://doi.org/10.1126/science.1231070

Linder P, Östlund L (1998) Structural changes in three mid-boreal Swedish forest landscapes, 1885-1996. Biol Conserv 85:9-19. https://doi.org/10.1016/S0006-3207(97)00168-7

Lõhmus A, Kinks R, Soon M (2010) The importance of dead-wood supply for woodpeckers in Estonia. Balt For 16:11

Lonsdale D (2013) Ancient and other veteran trees: further guidance on management. Ancient Tree Forum, London, pp 1-212. https://ancienttreeforum.co.uk/wp-content/uploads/2015/02/ATF_book.pdf

Luna S, Gold M, Albert A, Ceccaroni L, Claramunt B, Danylo O, Haklay M, Kottmann R, Kyba C, Piera J, Radicchi A, Schade S, Sturm U (2018) Developing mobile applications for environmental and biodiversity citizen science: considerations and recommendations. In: Joly A, Vrochidis S, Karatzas K, Karppinen A, Bonnet P (eds) Multimedia tools and applications for environmental \& biodiversity informatics. Springer, Cham, pp 9-30

Major R (1967) The Ginkgo, the most ancient living tree-the resistance of Ginkgo biloba L. to pests accounts in part for the longevity of this species. Science 157:1270-1273

Manning A, Fischer J, Lindenmayer D (2006) Scattered trees are keystone structures - implications for conservation. Biol Conserv 132:311-321. https://doi.org/10.1016/j.biocon.2006.04.023

Mitchell R et al (2014) Ash dieback in the UK: A review of the ecological and conservation implications and potential management options. Biol Conserv 175:95-109. https://doi.org/10.1016/j.biocon.2014.04.019

Moir A (2013) The exceptional yew trees of England, Scotland and Wales. Q J For 107(203):185-191

Morin R, Liebhold A, Tobin P, Gottschalk K, Luzader E (2007) Spread of beech bark disease in the eastern United States and its relationship to regional forest composition. Can J For Res 37:726-736. https://doi. org/10.1139/X06-281

Mountford E, Peterken G (2003) Long-term change and implications for the management of wood-pastures: experience over 40 years from Denny Wood, New Forest. For Int J For Res 76:19-43. https://doi.org/ 10.1093/forestry/76.1.19

National Planning Policy Framework (2019) Ministry of Housing, Communities and Local Government. https://www.gov.uk/government/publications/national-planning-policy-framework-2. Accessed Aug 2019

National Trust (2017) Open data: 'limited access land' and 'always open land'. https://uk-nationaltrust. opendata.arcgis.com/. Accessed 08 Jan 2019

Owen K, Alderman D (2008) Ancient Tree Hunt: The minimum girth of ancient trees - a guide for verifiers. Ancient Tree Hunt (Ancient Tree Forum, Woodland Trust, Tree Register of the British Isles).

Palmer M, Palmer N (2000) The spiritual traveler - England, Scotland, Wales: the guide to sacred sites and pilgrim routes in Britain. HiddenSpring, New York

Pautasso M, Chiarucci A (2008) A test of the scale-dependence of the species abundance-people correlation for veteran trees in Italy. Ann Bot 101:709-715. https://doi.org/10.1093/aob/mcn010

Peterken G (1977) Habitat conservation priorities in British and European woodlands. Biol Conserv 11:223-236

Petit S, Watkins C (2003) Pollarding trees: changing attitudes to a traditional land management practice in Britain 1600-1900. Rural Hist 14:157-176. https://doi.org/10.1017/S0956793303001018

Phillips S (2008) Transferability, sample selection bias and background data in presence-only modelling: a response. Ecography 31:272-278. https://doi.org/10.1111/j.0906-7590.2008.5378.x

Pigott D (1992) The clones of common lime (Tilia $\times$ vulgaris Hayne) planted in England during the seventeenth and eighteenth centuries. New Phytol 121:487-493. https://doi.org/10.1111/j.1469-8137. 1992.tb02949.x

R Core Team (2018) R: A Language and Environment for Statistical Computing. R Foundation for Statistical Computing, Vienna. https://www.R-project.org

Rackham O (1967) the history \& effects of coppicing as a woodland practice, in the biotic effects of public pressures on the environment. Nature Conservancy, London 
Rackham O (1976) Trees and woodland in the British landscape. J. M. Dent, London

Rackham O (1986) History of the countryside. Dent, London

Rackham O (1994) The illustrated history of the countryside. Orion Publishing Group, London

Ranius T (2002) Influence of stand size and quality of tree hollows on saproxylic beetles in Sweden. Biol Conserv 103:85-91. https://doi.org/10.1016/S0006-3207(01)00124-0

Ranius T (2006) Measuring the dispersal of saproxylic insects: a key characteristic for their conservation. Popul Ecol 48:177-188. https://doi.org/10.1007/s10144-006-0262-3

Ranius T, Johansson P, Berg N, Niklasson M (2008) The influence of tree age and microhabitat quality on the occurrence of crustose lichens associated with old oaks. J Veg Sci 19:653-662. https://doi.org/10. 3170/2008-8-18433

Rasey A (2004) Priority woodland in the landscape for two bat BAP species: the importance of ancient trees and woodlands. Int Assoc Landscapeecol, 12th CONF, Cirencester, England

Read H (2000) Veteran Trees: A guide to good management. English Nature, Peterborough. https://www. naturalengland.gov.uk

Read H, Wheater C, Forbes V, Young J (2010) The current status of ancient pollard beech trees at Burnham Beeches and evaluation of recent restoration techniques. Q J For 104:109-120

Rocchini D, Hortal J, Lengyel S, Lobo J, Jiménez-Valverde A, Ricotta C, Bacaro G, Chiarucci A (2011) Accounting for uncertainty when mapping species distributions: the need for maps of ignorance. Prog Phys Geogr 35:211-226. https://doi.org/10.1177/0309133311399491

Rohner B, Bugmann H, Bigler C (2013) Estimating the age-diameter relationship of oak species in Switzerland using nonlinear mixed-effects models. Eur J For Res 132:751-764. https://doi.org/10. 1007/s10342-013-0710-5

Roux D, Ikin K, Lindenmayer D, Manning A, Gibbons P (2014) The future of large old trees in urban landscapes. PLoS ONE 9:e99403. https://doi.org/10.1371/journal.pone.0099403

Rubino D, McCarthy B (2003) Composition and ecology of macrofungal and myxomycete communities on oak woody debris in a mixed-oak forest of Ohio. Can J For Res 33:2151-2163. https://doi.org/10.1139/ x03-137

Rust S, Roloff A (2002) Reduced photosynthesis in old oak (Quercus robur): the impact of crown and hydraulic architecture. Tree Physiol 22:597-601. https://doi.org/10.1093/treephys/22.8.597

Schmeller D et al (2009) Advantages of volunteer-based biodiversity monitoring in Europe. Conserv Biol J Soc Conserv Biol 23:307-316. https://doi.org/10.1111/j.1523-1739.2008.01125.x

Seibold S, Hagge J, Müller J, Gruppe A, Brandl R, Bässler C, Thorn S (2018) Experiments with dead wood reveal the importance of dead branches in the canopy for saproxylic beetle conservation. For Ecol Manage 409:564-570. https://doi.org/10.1016/j.foreco.2017.11.052

Siitonen J (2001) Forest management, coarse woody debris and saproxylic organisms: Fennoscandian Boreal Forests as an example. Ecol Bull 49:11-41

Sist P, Mazzei L, Blanc L, Rutishauser E (2014) Large trees as key elements of carbon storage and dynamics after selective logging in the Eastern Amazon. For Ecol Manag 318:103-109. https://doi.org/10.1016/j. foreco.2014.01.005

Speight M (1989) Saproxylic invertebrates and their conservation. Nature and environment. Council of Europe, Strasbourg

Spencer J, Kirby K (1992) An inventory of ancient woodland for England and Wales. Biol Conserv 62:77-93. https://doi.org/10.1016/0006-3207(92)90929-H

Stagoll K, Knight E, Fischer J, Manning A, Lindenmayer D (2012) Large trees are keystone structures in urban parks. Conserv Lett 5:115-122. https://doi.org/10.1111/j.1755-263X.2011.00216.X

Stahle D (1996) Tree rings ancient forest relics. Arnoldia 56:2-10

Stevenson R L (1875-1876) Forest Note in Collected Essays. eBooks@Adelaide, Australia.

Svensson M, Johansson V, Dahlberg A, Frisch A, Thor G, Ranius T (2016) The relative importance of stand and dead wood types for wood-dependent lichens in managed boreal forests. Fungal Ecol 20:166-174. https://doi.org/10.1016/j.funeco.2015.12.010

Teacher A, Griffiths D, Hodgson D, Inger R (2013) Smartphones in ecology and evolution: a guide for the app-rehensive. Ecol Evol 3:5268-5278. https://doi.org/10.1002/ece3.888

Tulloch A, Possingham H, Joseph L, Szabo J, Martin T (2013) Realising the full potential of citizen science monitoring programs. Biol Conserv 165:128-138. https://doi.org/10.1016/j.biocon.2013.05.025

Venables W, Ripley B (2002) Modern Applied Statistics with S, 4th edn. Springer, New York

White J (1998) Estimating the Age of Large and Veteran Trees in Britain. Forestry Practice. Information Note FCIN 12

Williamson T, Barnes G, Pillatt T (2017) Trees in England: management and disease since 1600. University of Hertfordshire Press, Hertfordshire 
Woodland Trust (2001) Position statement on Ancient Trees. Woodland Trust, Grantham, UK. https://www. woodlandtrust.org.uk/publications/2013/09/ancient-trees-parkland-and-wood-pasture/

Woodland Trust (2017) Trees outside woods: in contributing to the ecological connectivity and functioning of landscapes. Woodland Trust, Grantham

Yunyun H, Xingang K, Junhui Z (2009) Variable relationship between tree age and diameter at breast height for natural forests in Changbai Mountains. J Notheast For Univ 37:38-42

Publisher's Note Springer Nature remains neutral with regard to jurisdictional claims in published maps and institutional affiliations.

\section{Affiliations}

\section{Victoria Nolan $^{1}$ (D) - Tom Reader $^{1}$ (D) $\cdot$ Francis Gilbert ${ }^{1}$ (D) Nick Atkinson $^{2,3,4}$}

Victoria Nolan

victorianolan888@gmail.com

1 Life Sciences Building, University of Nottingham, Nottingham NG7 2TQ, UK

2 Woodland Trust, Kempton Way, Grantham NG31 6LL, UK

3 Nottingham Trent University, Brackenhurst NG25 0QF, UK

4 NERC Centre for Ecology and Hydrology, Wallingford OX10 8BB, UK 